\title{
The Butterfly Effect in Psychiatry: A case example
}

\author{
Osman Ozdemir ${ }^{1}$, Pinar Guzel Ozdemir ${ }^{1}$, Ekrem Yilmaz ${ }^{1}$
}

ÖZET:

Psikiyatride kelebek etkisi: Bir olgu bildirimi

Kelebek etkisi karıșık dinamik sistemlerde bașlangıçtaki küçük bir deg̃işimin, beklenmedik büyük bir sonuca yol açmasıdır. Modern bilimde, bu teorinin fizik, matematik, mühendislik gibi alanların yanısıra biyoloji, psikololoji ve nörobilimde de uygulamaları bulunmaktadır. Bilișsel işlevlere dinamik yaklaşım insan gelişiminin karmaşık süreçlerinin yașam boyunca zihinsel, davranıșsal, nöronal ve sosyal sistemlerini ve herbiri arasındaki etkileșimini vurgulamaktadır. Psikiyatri pratiḡinde, birey ve çevresi arasındaki etkileșimin sonucu ortaya çıkan rahatsızlıkların anlaşılmasında kelebek etkisi faydalı olabilir. Bu yazıda psikososyal yüklenme etmeni sonrası gelișen depresif dönem nedeniyle elektrokonvulsif tedavi uygulanan bir vaka sunulmuștur.

Anahtar sözcükler: kelebek etkisi, karışık dinamik sistem, insan davranışı, psikiyatrik rahatsızlıklar, kaos teorisi

Journal of Mood Disorders 2014;4(1):34-7

\section{ABSTRACT:}

The butterfly effect in psychiatry: a case example

The butterfly effect is that a small change at one place in a complex dynamic system can lead to large and unexpected consequences. In modern science, the theory can have applications in physics, mathematics, engineering, as well as biology, psychology, and cognitive science. The dynamic approach to cognition emphasizes the complex process of human development including mental, behavioral, neural and social systems interacting with each other over the life course. Emotion-related experiences as the result of interaction between person and his environment have been useful for explaining the butterfly effect in psychiatry practice. Here, we report a patient with depressive episode that has developed after psychosocial stress and has been treated with electroconvulsive therapy.

Key words: butterfly effect, complex dynamic system, human behavior, mental disorders, chaos theory

Journal of Mood Disorders 2014;4(1):34-7

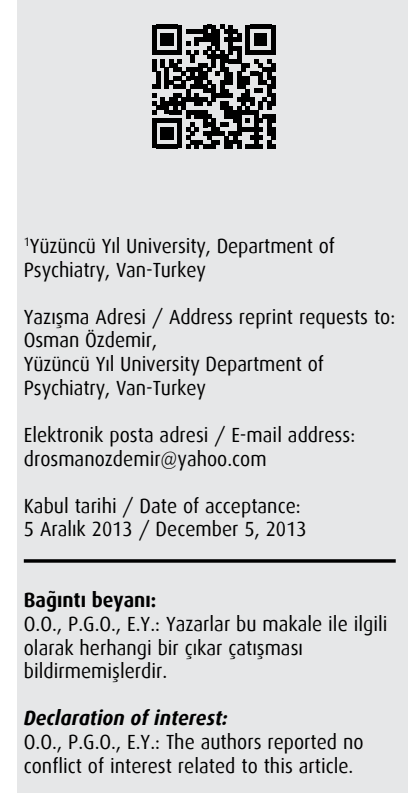

\section{INTRODUCTION}

In the chaos theory, the concept of the butterfly effect that was coined by an American mathematician and meteorologist Edward Lorenz is described as the sensitive dependence on initial conditions and nonlinear causal relationships; namely a small change at one place in a complex dynamic system such as atmosphere can lead to large and unexpected consequences. In 1972, he presented his thoughts and findings in his speech entitled "Predictability: Does the Flap of a Butterfly's Wings in Brazil Set off a Tornado in Texas?" at a meeting of the American Associationsfor theAdvancement of Sciencein Washington, D.C (1). The butterfly effect suggests that small, insignificant causes may contribute to huge and dramatic effects.

Although chaos theory was the initial term, complexity science, or complex systems theory, is often used to describe the chaotic behavior. Complexity theory focuses on the manner in which simple systems give rise to very complicated unpredictable behavior. These key concepts principally reflect nonlinear dynamical systems that are often characterized by instability, sudden unpredictable jumps, and discontinuous change, which are also called catastrophe theory $(2,3)$

\section{Nonlinear Dynamic Systems and Chaos Theory}

An unpredictable behavior of deterministic systems has been called chaos theory is an alternative name for "nonlinear dynamic systems theory". Chaos is one possible result of a dynamics of nonlinear system in which seemingly random events are predictable with simple deterministic equations. Chaotic phenomena that appear locally unstable but globally stable have a close relationship to notions such as attractors, bifurcations, fractals and self-organization (4). 
A chaotic attractor is a geometric region in a two or three-dimensional space in which each variable have a complicated set of a fractal (non-integer) structure mainly characterized by a continuous change. The concept of bifurcation is a large and sudden qualitative change in the behavior of the dynamical systems, which are extremely sensitive to very little changes and have a structure of the quasi-periodic attractor exhibiting irregular and shortterm fluctuations $(5,6)$. The self-organization of complex systems is an adaptive process that arises out of the interactions between internal control mechanisms and environmental perturbations (7).

Nonlinearity refers to disproportional relationship among variables in dynamic systems that change over time (8). Dynamic systems theory is an area of mathematics used to describe the behavior of complex systems by employing differential-difference equations. In modern science, the theory can have applications in physics, mathematics, engineering, as well as biology, psychology, and cognitive science $(4,5,8)$.

\section{Dynamic Systems in Cognitive Science}

The dynamic approach to cognition emphasizes the complex process of human development including mental, behavioral, neural and social systems interacting with each other over the life course. This multidimensional psychophysiological perspective includes the areas of motorskills, problemsolvingabilities, moralunderstanding, emotional development, and self-concept. These personality traits are determined by genetic, family, environmental, social, and cultural factors. Several researchers have made an effort to understand the interaction between these factors that may contain personal differences, individual thought patterns, perceptions of social events, attitudes toward social norms, intergroup relations, expectations, and their potential impact on development. In studies, there are different basic approaches applied with mathematical methods in measuring the dynamic behavior of complex psychological phenomena $(9,10)$. The psychological phenomena, which are a manifestation of mental processes reflecting feeling, thinking, motivation, interest, emotion, and ability, can exhibit from simple to more complex behaviors moving chaotic trajectories in some cases (9).

In cognitive science, the dynamic approach is also related to embodiment of the mind, and the environmental embeddedness or situatedness of cognition. Embodied cognitive science assumes that human behavior results from the physiological communication between mind and body, and the physical, social, cultural contexts within which activity occurs, presumably via the emotional system. The internal environment of the body or the milieu interieur is homeostatic and hormonal states, which are controlled by, inter related multiple dynamic equilibrium adjustment and regulation mechanisms that may be stable but sensitive to perturbations can be affected by environmental events.

Catastrophe theory is a branch of bifurcation theory and was developed for better understanding interactions within dynamical networks; small changes in certain parameters can lead to enormous effect on their attitudes, actions, and behaviors which are before seen as coherent, stable, consistent, and predictable (11). In social psychology, the applications of catastrophe theory has been used to explain the stages of psychomotor development, drastic and sudden changes in attitudes or behaviors, decision making processes, and to measure learning that shows general and specific cognitive abilities (12). Many psychological phenomena display the divergent or bimodal properties, discontinuity, inaccessibility, or hysteresis that can be interpreted with catastrophe theory $(12,13)$. The hysteretic human behavior may exhibit both present and history dependent features that are formed under the internal and external factors (11). A model of dynamic social behavior, the change of attitudes in a population, and other emotion-related experiences as the result of interaction between person and his environment have been useful for explaining catastrophe theory in social psychology and psychiatry practice $(12,14)$.

\section{CASE EXAMPLE}

A 40-year-old man was admitted to the in-patient psychiatric ward at our medical center with insomnia, lack of appetite, problems speaking, disregard for self-care, slow movements, weakness, and fatigue. The patient's complaints began one week ago, right after he had a debate with his uncle; the patient's cousin (his uncle's son) was hired for a municipal job that was promised to him. After this incident, he became lost in deep thought and became physically restless (walking, sitting down, and standing up 
within his house and walking aimlessly out of house). $\mathrm{He}$ described the episode as follows: "My whole world came crashing down," "I wished to die and end it, "and "I couldn't eat anything." For the two days leading up to his hospital visit, he did not speak, eat, sleep, or move.

The patient has a history of depression, including two major depressive episodes requiring hospitalization. The first happened twenty years ago, when he was a soldier. The second happened nine years ago, when he was working in another town. The latter included psychotic features that occurred after debating with his friends. Electroconvulsive therapy (ECT), fluoxetine $20 \mathrm{mg} /$ day, and risperidone $2 \mathrm{mg} /$ day were given as treatment. His brother also has a history of depression. According to his brother, the patient's premorbid personality traits were as follows: friendly, joyful, punctilious, honest, and hard working.

The following was found in his psychiatric examination: reduced self-care, poor eye contact, mutism, a markedly prolonged reaction time, one-word answers to questions, talking in a slow and quiet tone, negativism, resistance to our stimulations, marked decrease in responsiveness to the environment, spontaneous movement and activity, feelings of inappropriate guilt, apathetic mood, immobility, profound psychomotor retardation, maintenance of a rigid posture, decreased energy, low motivation, deceased appetite, and fatigue.

The patient was diagnosed as major depressive episode with catatonic features. He was hospitalized and given venlafaxine (75 mg/day), olanzapine (10 mg/day), and ECT. During clinical observation, the patient spent the vast majority of his day in bed, met his basic needs with help, walked with slow steps, and stood in the same position for long periods of time. Later, significant changes, such as increased psychomotor activity, emotional expression, and volume of speech, were observed. With eight sessions of ECT and pharmacotherapy, the patient made almost a full recovery at the end of four weeks hospitalization.

\section{DISCUSSION}

When human beings have a challenge or problem, they may experience many different feelings such as anxiety, fear, anger, and depression. In this case, the purpose of organization is developing strategies to improve its position. If these efforts fail, the movement will continue toward a bifurcation, chaotic behavior (7). The brain activity underlying complex human behaviors reflects cognitive processes involving consciousness. The complex brain dynamics do not allow estimation of expected behavior that is conscious experience. Each conscious states is a stream that has an extraordinary differentiation changing on a time scale of fractions of seconds $(15,16)$.

Human behavior can be massively affected by the experiences that seem unimportant and negligible in unexpected ways (1). In each case, there may be no correlation between abrupt or large behavioral changes and the presumed causes (12). These disproportionate causal effects are related with essential properties of the central nervous system functions that are regulated by multiple mechanisms and factors (17). A minor variation in the controlled factors may disrupt homeostasis in the brain and lead to psychiatric disorders such as depression, anxiety disorder, schizophrenia; as seen in the case here, as well (12).

\section{Homeostasis in The Brain and Mental Disorders}

The mental disorders are closely associated with physiological, social, and environmental factors (13). Any changes of these dynamic equilibrium states or homeostasis will result in the psychiatric disorders, especially in vulnerable individuals (18). For example, as seen in the presented case, thereare many different causes of depression such as stressful life events, lack of social connections and communal living challenges resulting in a final common pathway that is the dysfunction of neurotransmitters (serotonin, noradrenaline, and dopamine) that play very important roles in the regulation of a wide range of brain functions, including mood, attention, motivation, stress responses, sleep, appetite, and cognition (19-21).

In the normal state, homeostasis describes a process by which bodily systems maintain their normal healthy functions despite the impact of internal and external (such as social) factors are constantly changing (17). When potential compensatory psychophysiological mechanisms fail to meet expectations due to the relatively strong perturbations, an individual will emotionally experience different types of psychiatric disorders in various severity (22). Sometimes, the patient may develop catatonic symptoms that can be effectively treat with ECT.

It is well known that psychological distress may have potentially harmful effects on the regulatory and 
restorative processes of the body and mind in certain situations (22). Negative life events can precipitate many physical, behavioral, emotional mental problems including tension, headache, sadness, hopelessness, alcohol or drugs abuse, sleep disruption, decline in academic or work performance, and poor interpersonal communication $(17,22,23)$. The underlying psychoneuro-physiological hypersensitivity in some people shifts to a pathological response to outside stimuli such as a chaotic attractor and can develop severe mental disorders such as catatonic or psychotic depression, as seen in the above case. Chaotic, abnormal brain functions express mental illnesses, which are unpredictable and consequently dangerous situations (24). These actual pathoneurophysiological processes may generate

\section{References:}

1. Lorenz E. Predictability: Does the Flap of a Butterfly's Wings in Brazil Set off a Tornado in Texas? American Associations for the Advancement of Science $139^{\text {th }}$ Meeting in Washington. December 29, 1972.

2. Arrow H. Chaos, complexity, and catastrophe: The nonlinear Dynamics perspective. In S. A. Wheelan (Ed.), The handbook of group research and practice. Thousand Oaks, CA: Sage. 2005;201-19.

3. Maguire S, McKelvey B, Mirabeau L, Oztas N. Complexity science and organization studies. In: Clegg SR, Hardy C, Lawrence TB, Nord WR, editors. The SAGE Handbook Of Organization Studies. 2nd. London: Sage Publications; 2006.

4. Guastello SJ. What Is Chaos Theory? Chaos and Complexity in Psychology, Psyc 198 \& 896 Fall, 2007.

5. Kendall BE. Nonlinear Dynamics and Chaos. Encyclopedia of life sciences. 2001.

6. Murphy BK, Miller KD. Balancedamplification: a new mechanism of selective amplification of neural activity patterns. Neuron. 2009;61:635-48

7. Bloom SL. Chaos, complexity, self organization and US. The psychotherapy review. Ian G. Jones Healy Editor. PO Box 14 Teddington TW118YY UK. 2000.

8. Thelen E, Smith LB. Dynamic Systems Theories. Fusella PV. Dynamic Systems Theory in Cognitive Science: Major Elements, Applications, and Debates Surrounding a Revolutionary MetaTheory Dynamical Psychology. 2013; p.258-307.

9. Kiel, LD. Managing Chaos and Complexity in Government: A New Paradigm for Managing Change, Innovation and Organizational Renewal. San Francisco: Jossey-Bass. 1994.

10. Downing, LL. A cusp catastrophe model of cult conversions, in D.O. O'Learyand G.S. McGhee (Eds.), War in Heaven, Heaven on Earth: Theories of the Apocalyptic, London: Equinox. 2005;221-35.

11. Flay BR. Catastrophe theory in social psychology: Some applications to attitudes and social behavior. Behavioral Science. 1978;23:335-50. unexpectable, observable, accidental or unintentional actions, behaviors, thoughts and feelings.

Consequently, the classic model accepted that as suggested in the experiment of Pavlov, a reflex is simple relation between the stimulus (cause) and response (effect) that refers to linear causality. Behavioral determinism seems to be rather inadequate to explain the brain functions as compared to a dynamic system consideration that represents fractal fluctuations and quantum bifurcation (24). It has been characterized by extreme sensitivity to initial values that maybe determined by the subjective experiences and interpretations, which result in very different mental phenomena (17). Finally, nonlinear dynamics and chaos theory may contribute to understand human behavior.

12. Maas HLJ, Kolstein R, Pligt J. Sudden Transitions in Attitudes Sociological Methods\&Research. 2003;32:125-52.

13. Muijs D, Reynolds D. Effective Teaching. Evidence and practice. London: SAGE Publications Ltd, 2005.

14. Tooni G, Edelman GM. Consciousness and complexity. Neuroscience 1998;182:1846-51.

15. Dhamala M, Pagnoni G, Wiesenfeld K, Berns GS. Measurements of brain activity complexity for varying mental loads. Phys Rev E Stat Nonlin Soft Matter Phys. 2002;65(4):041917.

16. Barton S. Chaos, Self-Organization, and Psychology. American Psychologist. 1994;49;5-14.

17. Bremner JD. Changes in Brain Volume in Major Depression. Depression: Mind And Body. 2005;2:2

18. Hasler G. Pathophysiology of depression: do we have any solid evidence of interest to clinicians? World Psychiatry. 2010;9:155-61.

19. Harris T. Recent developments in understanding the psychosocial aspects of depression. British Medical Bulletin. 2001;57:17-32.

20. Drevets WC, Price JL, Furey ML. Brain structural and functional abnormalities in mood disorders: implications for neurocircuitry models of depression. Brain Struct Funct. 2008;213:93-118.

21. Cacioppo JT, Berntson GG. The Brain, Homeostasis, and Health. Balancing Demands of the Internal and External milieu. The Oxford Handbook of Health Psychology, 2011;73-91.

22. Connor TJ, Leonard BE. Depression, Stress And Immunological Activation: The Role Of Cytokines In Depressive Disorders. Life sciences. 1998;62:583-606.

23. Bob P. Chaos, Cognition and Disordered Brain. Activitas Nervosa Superior. 2008;50: 114-117. 